ISSN 2078-6441. Вісник Львівського університету. Серія географічна. 2013. Випуск 42. С. 357-366. Visnyk of the Lviv University. Series Geography. 2013. Issue 42. P. 357-366.

$630 * 2(477.82)$

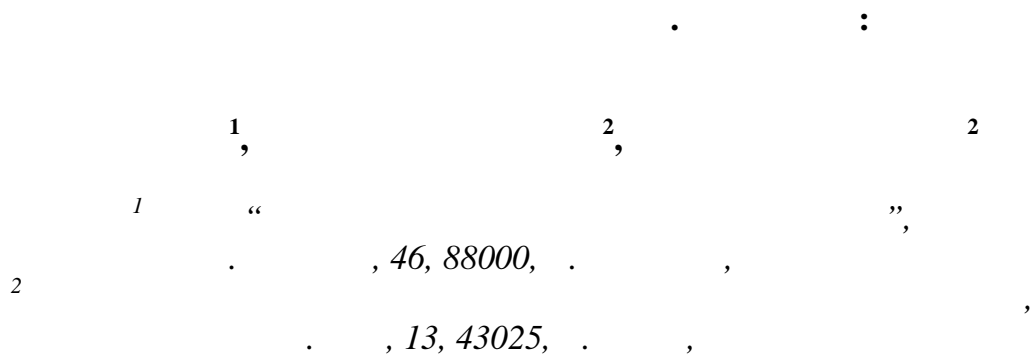

пис но й оцінено суч сний ст н лісового фонду б сейну р. ижівк . ро н лізов но ст тистичні д ні т дин міку з п сів лісового фонду, його породного скл ду т вікової структури лісон с джень. иділено групи лісів з господ рським зн ченням т основні види природокористув ння в меж х лісового фонду досліджув ної території. 'ясов но нег тивні т позитивні його сторони.

лючові слов : лісовий фонд, породний скл д лісів, віков структур деревост нів, з готівля деревини, лісовідновлення.

меж х 6 сейну р. ижівк зн чні площі вкриті лісовою рослинністю. т ном н 2013 р. площ лісових н с джень у досліджув ному регіоні ст новить 43,9 тис. г, у тому числі вкриті лісовою (деревною т ч г рниковою) рослинністю - 33,4 тис. г . лощ земель лісового фонду постійного користув ння збільшил сь н поч тку 2000-х років м йже н $26 \%$ порівняно з 90-ми рок ми століття.

ісистість території б сейну сьогодні ст новить 33,4 \%, тоді як у 2000 р. - 30,7 \%. ок зник лісистості колив ється в різних р йон х 6 сейну від 20,2 до 38,0 \% (т бл. 1).

ісистість території б сейну р. ижівк блиця 1

(з д ними олинського упр вління лісового господ рств н 01.01.2013 р.)

\begin{tabular}{|c|c|c|c|c|c|c|c|c|}
\hline \multirow{3}{*}{$\begin{array}{c}\text { риродн } \\
\text { одиниця }\end{array}$} & \multicolumn{2}{|c|}{ г льн лісистість, \% } & \multicolumn{5}{|c|}{ хищеність сільськогоспод рських угідь, \% } & \multirow{3}{*}{$\begin{array}{l}\text { iсо- } \\
\text { вкрит } \\
\text { площ , } \\
\text { тис. г }\end{array}$} \\
\hline & \multirow[t]{2}{*}{ Ф ктичн } & \multirow{2}{*}{$\begin{array}{c}3 \text { прогр - } \\
\text { мою з хисту } \\
\text { земель } \\
\text { інституту } \\
\text { землеустрою }\end{array}$} & \multicolumn{2}{|c|}{$\begin{array}{c}\text { полез хисні т } \\
\text { стокорегулюв льні } \\
\text { лісосмуги } \\
\end{array}$} & \multicolumn{3}{|c|}{$\begin{array}{c}\text { усім лісомеліор тив- } \\
\text { ними н с дженнями }\end{array}$} & \\
\hline & & & $\begin{array}{c}\text { Ф КТич- } \\
\text { н }\end{array}$ & $\begin{array}{l}3 \text { прогр - } \\
\text { мою }\end{array}$ & \begin{tabular}{|c} 
Ф ктич- \\
н
\end{tabular} & & $\begin{array}{l}\text { прогр - } \\
\text { мою }\end{array}$ & \\
\hline ерхня течія & 31,2 & 37,5 & 1,0 & 5,9 & 59,1 & & 83,8 & 20460,8 \\
\hline ередня течія & 34,3 & 36,6 & 5,0 & 8,0 & 59,0 & & 78,2 & 23717,1 \\
\hline ижня течія & 36,7 & 37,9 & 4,0 & 11,8 & 65,8 & & 89,5 & 7728,9 \\
\hline
\end{tabular}

зн чимо, що з ост нні 50 років лісистість регіону зросл м йже в $1,5 \mathrm{p} 3,3$ п с деревини в ліс х збільшився у 2,5 р з . лощ земель лісового фонду м є тенденцію до зрост ння з вдяки щорічному вис джув нню молодих дерев. більшення з п су лісового фонду відбулося по всіх груп х порід [9]. ин мік з п су лісового фонду пок 3 н н рис. 1.

(C) ир ., ельнійчук ., ч ровський ., 2013 


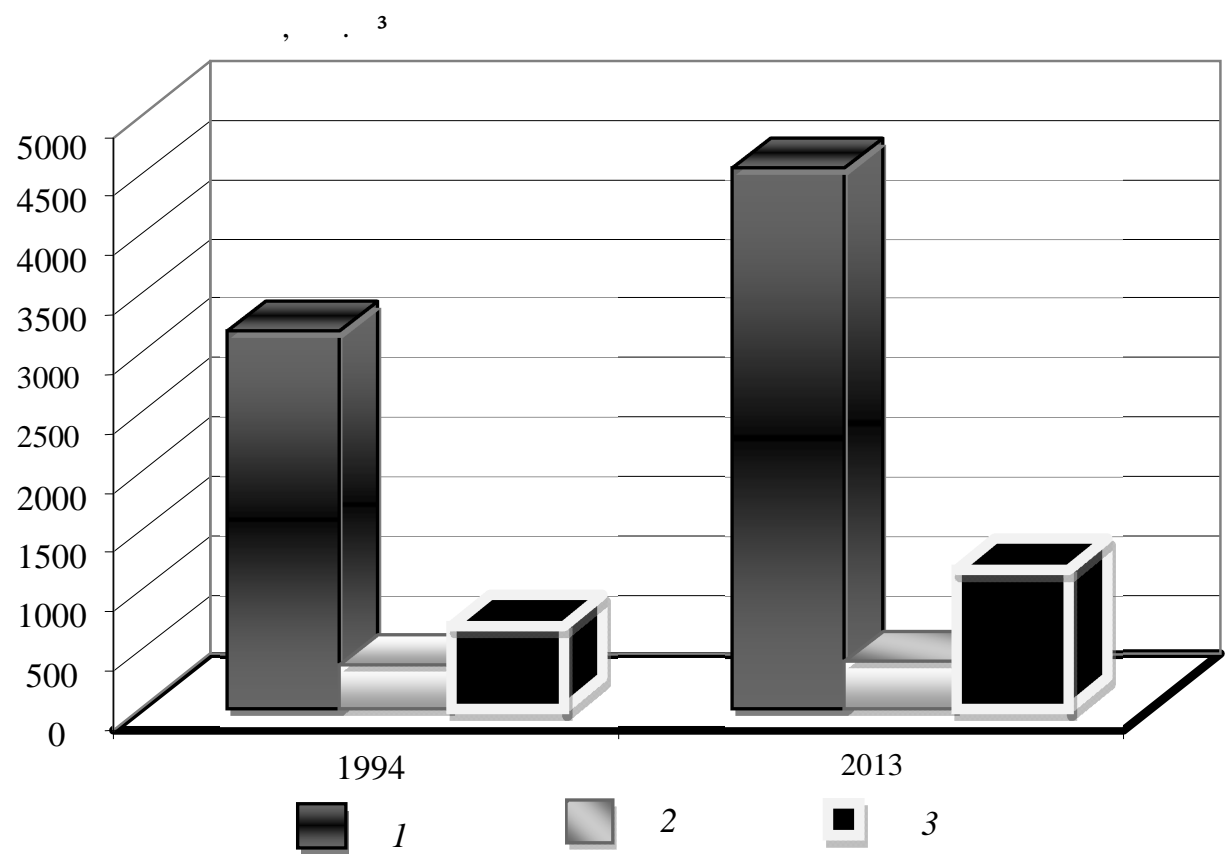

ис. 1. і гр м дин міки з п су лісового фонду 6 сейну р. ижівк : 1 - хвойні; 2 - твердолистяні; 3 - м'яколистяні.

лісост н х лісових господ рств 6 сейну перев ж ють хвойні ліси $(74,4 \%)$, м'яколистяні $(19,1 \%)$ і твердолистяні $(6,5 \%)$. ьогодні відбув ється змін породного скл ду лісів у н прямі збільшення цінних і продуктивних порід дерев ун слідок скорочення площ похідних деревост нів і з міни м лоцінних н с джень ціннішими і продуктивнішими. ин мік скл ду лісового фонду з груп ми порід проілюстров н н рис. 2. ді гр м б чимо, що з ост нні роки відбулось незн чне зменшення відсотк хвойних лісів (н $0,6 \%$ ), н 2,6\% збільшились площі м'яколистяних лісів т зменшились площі твердолистяних [8].

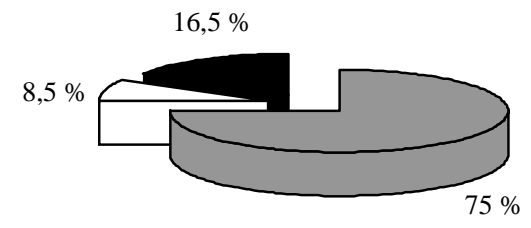

1994 рік

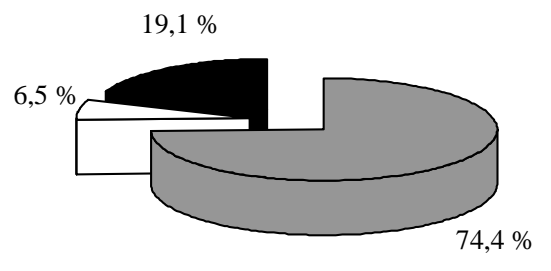

$2 \square 3$

2012 рік
列

ис. 2. ин мік скл ду лісового фонду з груп ми порід:

1 - хвойні; 2 - твердолистяні; 3 - м'яколистяні. 
жливим пок зником, що х р ктеризує лісовий фонд, є породний скл д. озподіл вкритих лісовою рослинністю земель 3 перев жними пород ми т кий, \%: сосн звич йн - 67,3; ялин європейськ - 0,3; дуб звич йний $-5,7$; дуб черешковий $-0,1$; гр б звич йний $-0,2$; ясен звич йний $-0,1$; берез повисл $-9,5$; осик $-0,3$; вільх чорн $-16,5$.

дин міці вікової структури лісон с джень простежено зн чне збільшення ч стки середньовікових, пристиг ючих і стиглих н с джень, що веде до збільшення об'єму використ ння лісового фонду (рис. 3). ередній вік деревост нів лісового фонду 6 сейну перевищуе 55 років. олодняки 3 йм ють $39,7 \%$, середньовікові - 43,3, пристиг ючі - 12,6, стиглі й перестиглі - 4,4\%. собливо низький відсоток стиглих н с джень з перев ж нням цінних деревних порід - сосни звич йної і дуб черешкового [1]. бл сне упр вління лісового господ рств , проводячи вирубку цінних сосноводубових н с джень н території б сейну, не змогло з безпечити відновлення цих порід, тому н сотнях гект рів з'явився с мосів березово-вільхових порід [5].

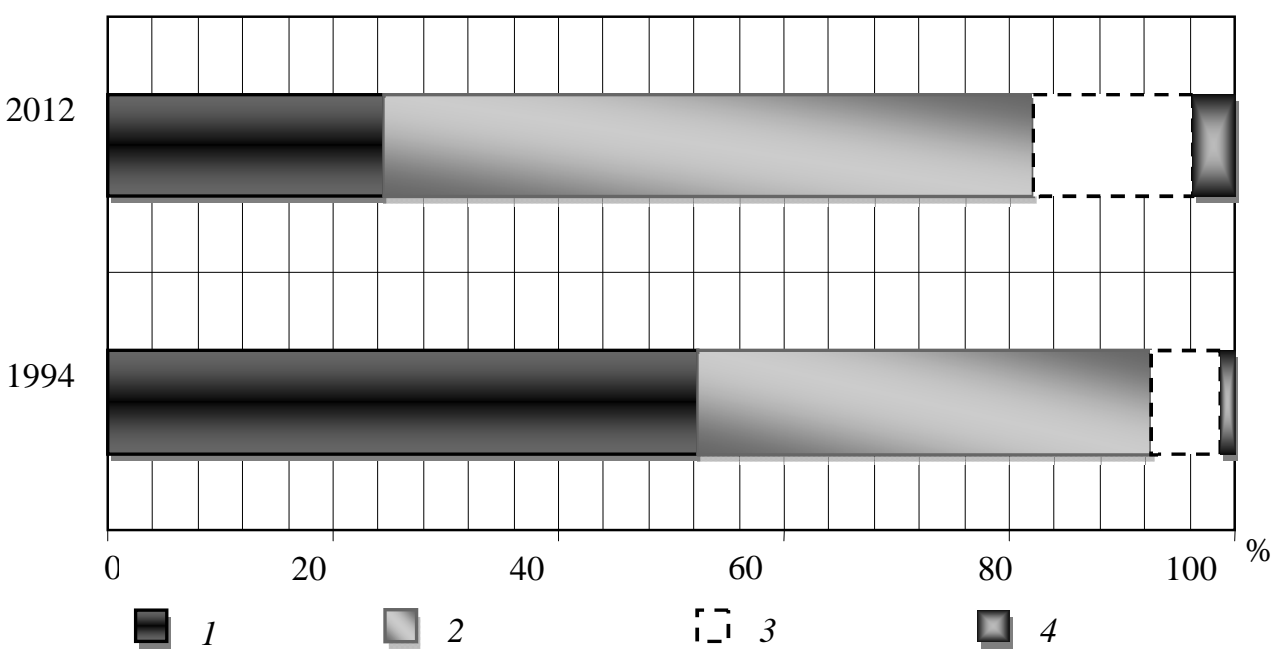

ис. 3. і гр ми дин міки вікової структури н с джень основних лісоутворюючих порід: 1 - молодняки; 2 - середньовікові; 3 - пристиг ючі; 4 - стиглі т перестиглі.

явний поділ н с джень основних лісоутворюв льних порід з груп ми віку не відповід є оптим льному. оптим льного розподілу молодняку, середньовікових, пристиг ючих т стиглих і перестиглих порід у співвідношенні, відповідно, $38,5: 30,6: 19,3: 11,6$ ми м ємо ф ктичний розподіл у б сейні в співвідношенні $24,4: 57,6: 14,2: 3,8$ [6]. обто 3 всім груп ми порід 3 фіксов но менші площі н с джень молодняку, пристиг ючих, стиглих і перестиглих порід, ніж оптим льні.

період 1994-2012 pp. у б сейні p. ижівк збільшився з г льний з п с сосни нкс н 0,04 тис. $\mathrm{M}^{3}$, сосни еймут н 0,19 тис. $\mathrm{m}^{3}$, сосни звич йної н 1252,79 тис. $\mathrm{M}^{3}$, ялини європейської н 5,25 тис. $\mathrm{m}^{3}$, модрини європейської н 0,15 тис. $\mathrm{m}^{3}$, дуб червоного н 1,4 тис. $\mathrm{m}^{3}$, дуб звич йного н 33,04 тис. $\mathrm{m}^{3}$, к ції білої н 0,02 тис. $\mathrm{M}^{3}$, берези повислої н 110,63 тис. $\mathrm{m}^{3}$, осики н 8,59 тис. $\mathrm{M}^{3}$, вільхи чорної н 357,07 тис. $\mathrm{M}^{3}$, тополі чорної н 1,45 тис. $\mathrm{M}^{3}$. одноч с зменшився 3 г льний 
3 п с дуб скельного н 0,3 тис. $\mathrm{M}^{3}$, гр 6 звич йного 11,21 тис. $\mathrm{M}^{3}$, ясен звич йного н 22,1 тис. $\mathrm{m}^{3}$, ясен зеленого н 0,18 тис. $\mathbf{m}^{3}$, тополі к н дської н 0,42 тис. $\mathrm{m}^{3}$ т верби козячої н 0,12 тис. $\mathrm{M}^{3}$.

вдяки сприятливим природно-клім тичним умов м ліси регіону м ють високу продуктивність. ічний приріст деревини 31 г покритої лісом площі ст новить у середньому пон д 3,5-4,0 м³. е пояснюють перев ж нням молодих середньовікових лісів у структурі лісового фонду. оч для лісових н с джень х р ктерн середня продуктивність, з те вони м ють високу біологічну стійкість.

господ рським зн ченням ліси досліджув ного б сейну поділяють н дві групи [4]. о лісів першої групи н леж ть зелені зони міст і сіл, водоохоронні зони вздовж річок, поле- і грунтоз хисні смуги, з хисні смуги об біч шосейних доріг і з лізниць. они з йм ють 6880,5 г , бо 22,6 \% площі, вкритої лісовою рослинністю. роведення рубок цієї групи лісів обмежене. они виконують перев жно водоохоронні, з хисні, с ніт рно-гігієнічні т оздоровчі функції.

хисні смуги лісів уздовж втомобільних доріг держ вного зн чення ст ном н 2012 р. $з$ йм ли 1013 г площі б сейну. е н 166 г більше, ніж у 1994 р. лощ 3 хисних смуг лісів уздовж з лізниць теж збільшил сь н 85 г, лісогоспод рської ч стини лісів зеленої зони - н 152 г .

озитивною є тенденція у дин міці площ смуги лісів уздовж берегів річок, озер т водоймищ - н 542 г . г лом площ лісів, які н леж ть до першої к тегорії, з ост нні 15 років збільшил сь н 945 г (т бл. 2).

рупи і к тегорії з хисності лісів у б сейні р. ижівк

блиця 2

(з д ними олинського упр вління лісового господ рств н 01.01.2013 p.)

\begin{tabular}{|c|c|c|c|c|c|c|}
\hline \multirow{3}{*}{ рупи і к тегорії лісів } & \multicolumn{4}{|c|}{ лощ } & \multicolumn{2}{|c|}{ міни } \\
\hline & \multicolumn{2}{|c|}{$\begin{array}{l}\text { ст ном н } \\
01.01 .1994\end{array}$} & \multicolumn{2}{|c|}{$\begin{array}{l}\text { ст ном н } \\
01.01 .2013\end{array}$} & \multirow[t]{2}{*}{,$\pm \Gamma$} & \multirow[t]{2}{*}{, $\pm \%$} \\
\hline &,$\pm \Gamma$ &, $\pm \%$ &,$\pm \Gamma$ &, $\pm \%$ & & \\
\hline \multicolumn{7}{|c|}{ іси першої групи } \\
\hline $\begin{array}{l}\text { хисні смуги лісів уздовж } \\
\text { дтомогобільних } \\
\text { держ вного зн чення }\end{array}$ & 847 & 2,7 & 1013 & 2,5 & +166 & $+19,6$ \\
\hline хисні смуги лісів уздовж з лізниць & 1110 & 3,5 & 1195 & 3,0 & +85 & $+7,7$ \\
\hline ісогоспод рськ ч стин лісів зеленої зони & 277 & 0,9 & 429 & 1,1 & +152 & $+54,9$ \\
\hline $\begin{array}{l}\text { муги лісів уздовж берегів річок, озер, } \\
\text { водоймищ }\end{array}$ & 4546 & 14,3 & 5088 & 12,7 & +542 & $+11,9$ \\
\hline зом лісів першої групи & 6780 & 21,4 & 7725 & 19,3 & +945 & $+13,9$ \\
\hline \multicolumn{7}{|c|}{ іси другої групи } \\
\hline ксплу т ційні ліси & 24956 & 78,6 & 32235 & 80,7 & +7279 & $+29,2$ \\
\hline
\end{tabular}

іси другої групи з йм ють 33,8 тис. г , бо 77,4 \% площі. о них н леж ть експлут ційні ліси, т кож лісові спецзони і спецсмуги, які поряд з екологічним, м ють експлу т ційне зн чення. лощ лісів цієї групи порівняно з 1994 р. збільшил сь н $29 \%$, в числовому еквів ленті- н 7279 г. нші лісові землі з йм ють 533,6 г, ч г рники $-1737,1$ г . 
одо площ, які не вкриті лісом, ділянки з нез'єдн ними лісовими культур ми, лісопросіки, зг рищ, болот, з болочені сіножі, то вони з йм ють у меж х б сейну 807,6 г . роте якщо 1994 р. т кі землі з йм ли 787 г, то у 2012 р. - 1114 г, що н $41,5 \%$ більше.

г лом н території досліджув ного б сейну зрост ють 73 види рослин, які з несені до ервоної книги кр їни, 7 видів флори, які є під охороною ернської конвенції, т 10 видів рослин, що з несені до вропейського червоного списку. е лілія лісов , зозулині черевички, конв лія тр внев , в лері н лік рськ, медунк лік рськ, бул тк червон, росинк нглійськ , 6 р нець звич йний, молоч й волинський, сон чорніючий, жур влин дрібнолист, вовчі ягоди п хучі, зозулині черевички спр вжні, цибуля ведмеж, осок з тінков , підсніжник білосніжний, п пороть, чорниця, лохин , чистотіл і сон-тр в , м рсилія чотирилист , с львінія пл в юч , горіх водяний пл в ючий [3].

уч сн з готівля деревини в меж х 6 сейну не перевищує розр хункової лісосіки.

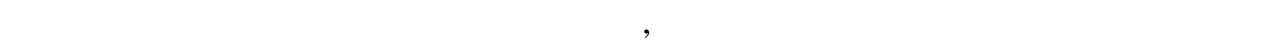
низький. е пояснюють перев ж нням молодняків т середньовікових н с джень, високою ч сткою лісів з обмеженим режимом лісокористув ння (н 47 \% лісів поширюється з борон головних рубок), неповним використ нням ліміту лісосічного фонду [2].

кономічн криз спричинил зниження обсягів з готівлі деревини в меж х 6 сейну. ередній пок зник з готівлі деревини 3 ост нні роки ст новить 35,76 тис. м $^{3}$. них від рубок головного користув ч - 20,8 тис. м $^{3}$, від рубок, пов'яз них з веденням лісового господ рств $,-14,9$ тис. $\mathrm{M}^{3}$ (т бл. 3 ).

блиця 3

бсяги продукції лісового господ рств і з готівля ліквідної деревини в меж х 6 сейну p. ижівк (з д ними олинського упр вління лісового господ рств н 01.01.2013 p.)

\begin{tabular}{|c|c|c|c|c|c|c|}
\hline \multirow{3}{*}{ 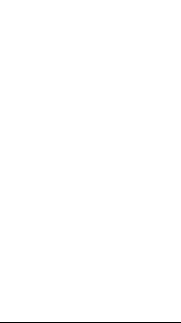 } & \multicolumn{6}{|c|}{ готовлено деревини, щільних м³ } \\
\hline & \multirow[b]{2}{*}{$\begin{array}{l}0 \\
0 \\
0 \\
0 \\
0 \\
0\end{array}$} & \multicolumn{2}{|c|}{ В Т.Ч. } & \multicolumn{3}{|c|}{$\begin{array}{c}\text { із з г льної кількості з готовленої } \\
\text { деревини }\end{array}$} \\
\hline & & 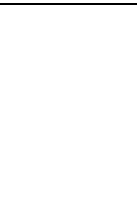 & 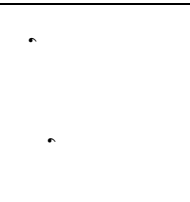 & 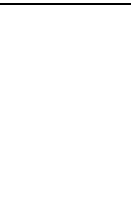 & 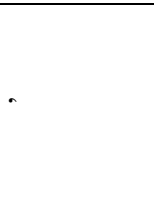 & 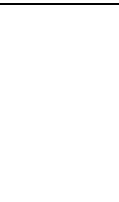 \\
\hline ерхня течія & 12464,5 & 6525,5 & 5939,1 & 4051,7 & 4345,4 & 3963,2 \\
\hline ередня течія & 14949,0 & 8673,5 & 6275,9 & 6310,0 & 5550,4 & 3089,0 \\
\hline ижня течія & 8347,0 & 5609,0 & 2738,2 & 3786,8 & 2518,3 & 2042,0 \\
\hline сього & 35760,5 & 20808,0 & 14953,2 & 14148,5 & 12414,1 & 9094,2 \\
\hline
\end{tabular}

одноч с зросл $з$ готівля ліквідної деревини. орічний обсяг з готівлі ліквідної деревини від усіх видів рубок у б сейні ст новить приблизно 36 тис. м ${ }^{3}$ і ід рубок головного користув ч обсяг з готівлі ліквідної деревини ст новить пон д 20 тис. м², від рубок, пов'яз них із веденням лісового господ рств , - 15 тис. м³. 3 г г льної кількості з готовленої деревини $40 \%$ йде н виробництво лісом тері лів круглих, 35 - н 3 готівлю деревини для технологічних потреб, решт $25 \%$ з готовляють як дров н оп лення. 
ин мік пок зник з готівлі ліквідної деревини від усіх видів рубок пок 3 н н рис. 4. орічний приріст з готівлі деревини ст ном н 2012 р. ст новив 57,9 тис. м $^{3}$, у 2005 р. - н 10 тис. м³ менший і дорівнюв в 42,7 тис. м $^{3}$, у 2000 p. - 35,3 тис. м².

зн чимо, що суч сні обсяги з готівлі деревини зн чно обмежені вн слідок збільшення площі $з$ хисних і $з$ повідних територій у ліс х. ур хув нням н копичення з п сів стиглих і перестійних н с джень н йближчими рок ми об'єктивним є збільшення норми з готівлі деревини в ліс х досліджув ного регіону н 10-15\% [2].

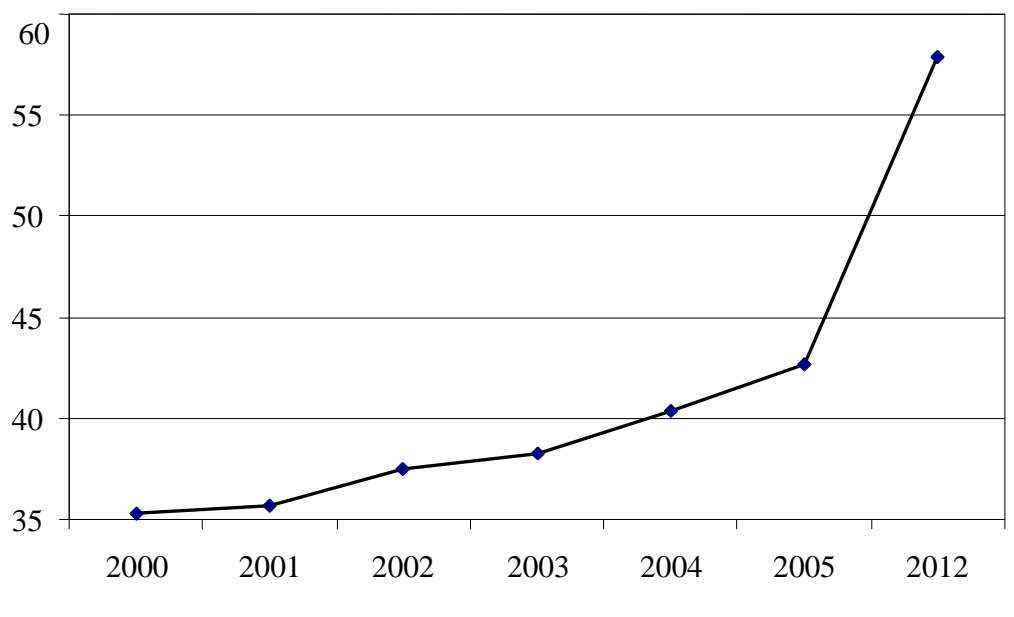

ис. 4. р фік дин міки з готівлі ліквідної деревини.

ункт ми вивезення деревини н території б сейну є смт т $\mathrm{p}$ ижівк і цех переробки деревини убечнівського лісництв .

н слідок змін вікової структури лісового фонду н мітився перехід до інтенсифік ції рубок догляду. томість у ліс х, що вилучені з експлу т ції, відбув лося н копичення з п сів стиглого лісу. т ких умов підприємств лісового господ рств змушені проводити м лоефективні вибіркові с ніт рні рубки дерев, що всих ють, освітлення і прочищення лісу через недост тне фін нсув ння скоротилися, що ч сто зумовлює неб ж ну зміну порід. 1994-2013 рр. площ з гиблих деревост нів у регіоні зросл у 2,3 p 3 .

р ктеристик з проектов них обсягів рубок догляду н веден в т бл. 4.

ин мік спеці льного використ ння лісових ресурсів свідчить про зн чне зрост ння всіх видів рубок (особливо лісовідновних і суцільно-с ніт рних).

т ном н 2013 р. у меж х 6 сейну виявлено 5,4 г стиглих, перестійних, пристиг ючих і середньовікових деревост нів, вилучених із розр хунку головного користув ння лісом, що втр ч ють з хисні, водоохоронні й інші корисні вл стивості, у яких рекомендують проведення лісовідновних рубок. підст ві з г льного обсягу лісовідновних рубок, ф ктичного ст ну н с джень, у яких рекомендов ні ці рубки, їх доцільно провести 3 дв роки, тобто щорічно н площі 2,7 г і з г льним з п сом стовбурної деревини 0,40 тис. $\mathrm{m}^{3}[8]$.

звемо і позитивні спекти природокористув ння. о них н лежить лісовідновлення - комплекс з ходів з відновлення лісів н зруб х, зг рищ х, г лявин х, пустири- 
щ х т інших площ х, що були під лісом [7]. о лісовідновлення входить пос дк , посів лісу т його природне поновлення. ля більшості дміністр тивних р йонів, які $€$ в $б$ сейні p. ижівк, х р ктерн тенденція до зрост ння обсягів лісовідновлення т пос дки і посіву лісу в лісовому фонді впродовж 1994-2012 pр. (див. т бл. 5, 6).

блиця 4

p ктеристик $з$ проектов них обсягів рубок догляду в меж х 6 сейну р. ижівк

(з д ними олинського упр вління лісового господ рств н 01.01.2013 р.)

\begin{tabular}{|c|c|c|c|c|c|c|}
\hline \multirow[b]{2}{*}{ ок зники } & \multirow{2}{*}{$\begin{array}{c}\text { диниці } \\
\text { вимірю- } \\
\text { в ння }\end{array}$} & \multicolumn{4}{|c|}{ иди рубок догляду } & \multirow[b]{2}{*}{ 30M } \\
\hline & & $\begin{array}{c}\text { освітлен- } \\
\text { ня }\end{array}$ & $\begin{array}{c}\text { просвіт- } \\
\text { лення }\end{array}$ & $\begin{array}{c}\text { прорі- } \\
\text { Джув ння }\end{array}$ & $\begin{array}{c}\text { прохідні } \\
\text { рубки }\end{array}$ & \\
\hline \multicolumn{7}{|c|}{ войне } \\
\hline лощ & $\Gamma$ & 41,7 & 78,6 & 188,9 & 106,2 & 415,4 \\
\hline п с, який вирубують: & тис. $\mathrm{M}^{3}$ & & & & & \\
\hline - стовбурний & тис. $\mathrm{M}^{3}$ & 0,18 & 0,59 & 3,85 & 2,44 & 7,06 \\
\hline - ліквідний & тис. $\mathrm{M}^{3}$ & 0,01 & 0,3 & 3,28 & 2,21 & 5,80 \\
\hline - ділової деревини & тис. $\mathrm{M}^{3}$ & - & - & 0,96 & 0,99 & 1,95 \\
\hline $\begin{array}{l}\text { товбурний з п с, який } \\
\text { вирубують з } 1 \text { г }\end{array}$ & $\mathrm{M}^{3}$ & 3,9 & 7,5 & 20,3 & 22,9 & - \\
\hline \multicolumn{7}{|c|}{ вердолистяне } \\
\hline лощ & $\Gamma$ & 1,9 & 5,6 & 13,2 & 1,1 & 21,8 \\
\hline п с, який вирубують: & тис. $\mathrm{M}^{3}$ & & & & & \\
\hline - стовбурний & тис. $\mathrm{M}^{3}$ & 0,01 & 0,05 & 0,20 & 0,03 & 0,29 \\
\hline - ліквідний & тис. $\mathrm{M}^{3}$ & - & 0,01 & 0,16 & 0,03 & 0,20 \\
\hline - ділової деревини & тис. $\mathrm{M}^{3}$ & - & - & 0,04 & 0,01 & 0,05 \\
\hline $\begin{array}{l}\text { товбурний з п с, який } \\
\text { вирубують } 31 \text { г } \\
\end{array}$ & $\mathrm{M}^{3}$ & 3,4 & 8,7 & 16,2 & 27,3 & - \\
\hline \multicolumn{7}{|c|}{ 'яколистяне } \\
\hline лощ & $\Gamma$ & 63,8 & 82,3 & 170,2 & 90,4 & 406,7 \\
\hline п с, який вирубують: & тис. $\mathrm{M}^{3}$ & & & & & \\
\hline - стовбурний & тис. $\mathrm{M}^{3}$ & 0,29 & 0,66 & 3,40 & 2,09 & 6,44 \\
\hline - ліквідний & тис. $\mathrm{M}^{3}$ & 0,02 & 0,29 & 2,85 & 1,88 & 5,04 \\
\hline - ділової деревини & тис. $\mathrm{M}^{3}$ & - & - & 0,82 & 0,82 & 1,64 \\
\hline $\begin{array}{l}\text { товбурний } 3 \text { п с, який } \\
\text { вирубують } 31 \text { г }\end{array}$ & $\mathrm{M}^{3}$ & 4,3 & 7,9 & 19,9 & 23,0 & - \\
\hline
\end{tabular}

блиця 5

ос дк і посів лісу в лісовому фонді в меж х 6 сейну р. ижівк , г (з д ними олинського упр вління лісового господ рств н 01.01.2013 p.)

\begin{tabular}{|c|c|c|c|c|c|c|c|c|c|c|c|}
\hline \multirow{2}{*}{$\begin{array}{c}\text { ри родн } \\
\text { одиниця }\end{array}$} & $\mathbf{1 9 9 4}$ & $\mathbf{1 9 9 6}$ & $\mathbf{1 9 9 7}$ & $\mathbf{1 9 9 8}$ & $\mathbf{1 9 9 9}$ & $\mathbf{2 0 0 0}$ & $\mathbf{2 0 0 1}$ & $\mathbf{2 0 0 2}$ & $\mathbf{2 0 0 3}$ & $\mathbf{2 0 0 4}$ & $\mathbf{2 0 1 2}$ \\
\hline ерхня течія & 35,1 & 43,4 & 36,8 & 32,8 & 30,9 & 40,1 & 37,4 & 40,7 & 41,1 & 43,6 & 56,4 \\
\hline ередня течія & 127,6 & 99,1 & 44,0 & 132,6 & 82,4 & 82,4 & 75,6 & 73,1 & 48,3 & 52,7 & 129,5 \\
\hline ижня течія & 33,9 & 27,8 & 30,8 & 21,1 & 22,4 & 27,5 & 26,8 & 34,7 & 38,5 & 41,3 & 54,6 \\
\hline сього & 196,6 & 198,6 & 111,6 & 186,5 & 135,7 & 141,0 & 139,8 & 148,5 & 127,9 & 137,6 & 240,5 \\
\hline
\end{tabular}


ісокористув чі щорічно проводять роботи з лісовідновлення н суцільних зруб х, у з болочених місцях ділянки відводять під природне відновлення, проводять 3 ліснення неприд тних для ведення сільського господ рств земель. ст нніми рок ми обсяги створення нових н с джень н сільськогоспод рських угіддях зрост ють. ісові культури головно створюв ні монокультур ми, хоч треб звернути ув гу н створення н с джень зміш ного скл ду [1].

блиця 6

ісовідновлення в лісовому фонді в меж х 6 сейну р. ижівк , г

(з д ними олинського упр вління лісового господ рств , н 01.01.2013 р.)

\begin{tabular}{|c|c|c|c|c|c|c|c|c|c|c|c|}
\hline \multirow{2}{*}{$\begin{array}{c}\text { риродн } \\
\text { одиниця }\end{array}$} & \multicolumn{10}{|c|}{ оки } \\
\cline { 2 - 13 } & $\mathbf{1 9 9 4}$ & $\mathbf{1 9 9 6}$ & $\mathbf{1 9 9 7}$ & $\mathbf{1 9 9 8}$ & $\mathbf{1 9 9 9}$ & $\mathbf{2 0 0 0}$ & $\mathbf{2 0 0 1}$ & $\mathbf{2 0 0 2}$ & $\mathbf{2 0 0 3}$ & $\mathbf{2 0 0 4}$ & $\mathbf{2 0 1 2}$ \\
\hline ерхня течія & 39,7 & 46,7 & 42,5 & 38,3 & 39,8 & 39,3 & 45,6 & 59,0 & 68,7 & 67,4 & 71,4 \\
\hline ередня течія & 127,0 & 99,1 & 149,3 & 262,1 & 113,4 & 120,2 & 137,5 & 110,3 & 71,9 & 66,9 & 143,7 \\
\hline ижня течія & 39,2 & 31,4 & 34,9 & 26,2 & 28,5 & 40,4 & 38,5 & 43,9 & 60,9 & 61,8 & 67,5 \\
\hline сього & 205,9 & 177,2 & 226,7 & 326,6 & 181,7 & 199,9 & 221,6 & 213,2 & 201,5 & 196,1 & 282,6 \\
\hline
\end{tabular}

ин мік пос дки лісу в меж х досліджув ного 6 сейну пок 3 н к 6 чимо з гр фік, обсяги пос дки лісу зн чно колив лись у ч совому розрізі. 1995-1996 рр. обсяги пос дки лісу були в меж х 198 г . 1997 р. цей пок зник різко скоротився до 110 г . оступове підвищення обсягу посіву лісу (після різкого стрибк у бік збільшення 1998 р.) відбув л ся з 1999 р. йвищий пок зник ост нніми рок ми спостеріг ли 2005 р. - 240,5 г . 2006 р. дин мік обсягів посіву лісу пішл н сп д. окрем , у 2012 р. н досліджув ній території посіяли лише 168,9 г лісу.

лощ , г

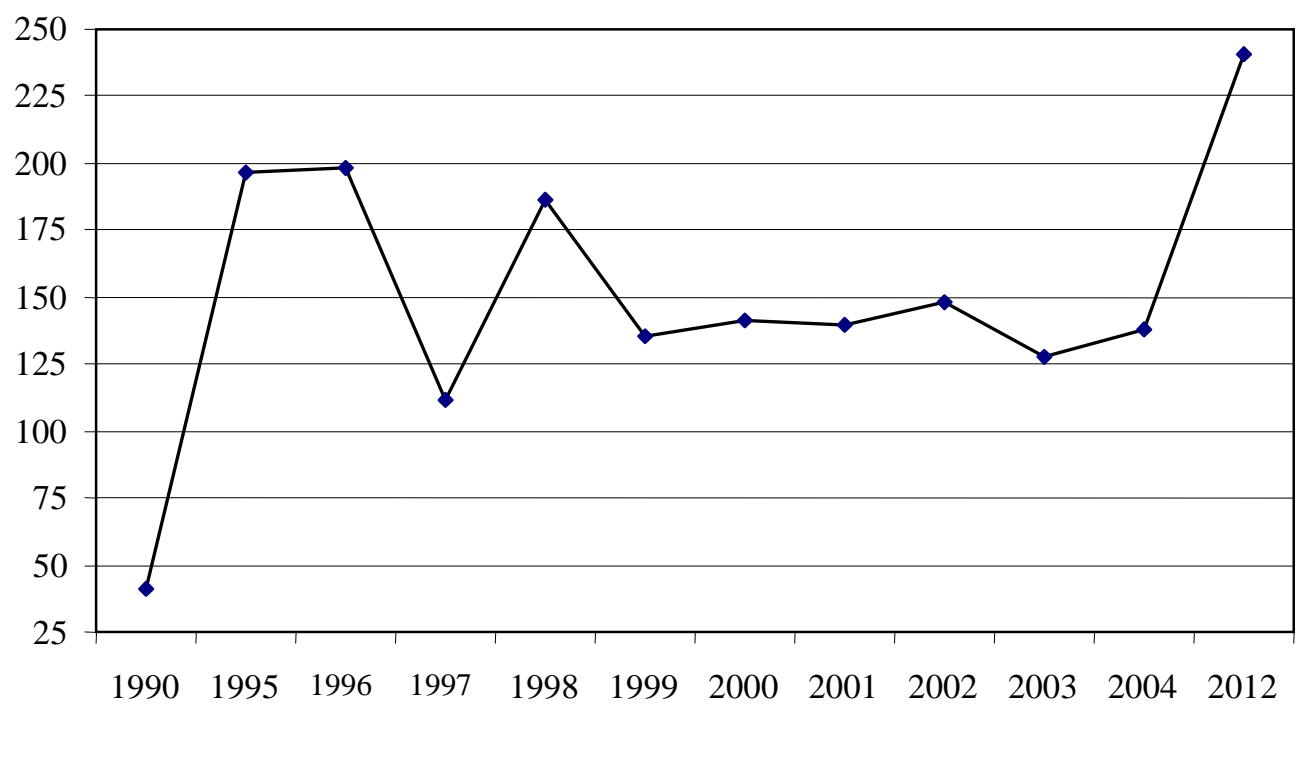

ис. 5. рив дин міки пос дки лісу в лісовому фонді б сейну р. ижівк . 
ст нніми рок ми зн чно зросли нез конні рубки дерев. ісокористув чі постійно проводять роботу з боротьби із с мовільними рубк ми, для чого створюють мобільні групи з пр цівників лісової охорони, з луч ють т кож пр цівників пр воохоронних орг нів, одн к обсяги рубок не зменшуються.

еликої шкоди н с дженням з вд ють лісові пожежі. т тистик з свідчує, що в середньому з рік у б сейні річки тр пляється по вісім-десять пожеж. ричини їхнього виникнення різном нітні: від спеки до необережного поводження з вогнем т підп лу. прикл д, у 2000 р. н досліджув ній території з фіксов но вісім пожеж, які охопили площу 6,5 г , 2012 р. кількість вип дків лісових пожеж збільшил сь до 11, зросл і площ їхнього поширення до 9г. ростежити з кономірності дин міки виникнення лісових пожеж у регіоні неможливо. дебільшого вони виник ють з вини н селення вн слідок недотрим ння пр вил протипожежної безпеки в ліс х у пожежонебезпечний період.

готівля дикорослих плодів, ягід, грибів, березового соку т очерету звич йного н території $б$ сейну відбув ється в меж х визн чених лімітів.

тже, лісовий фонд досліджув ного регіону $\epsilon$ ст білізув льним чинником у функціонув нні л ндш фту б сейну. ьогодні територія б сейну р. ижівк м є середню лісистість, якісний породний скл д т неоптим льну вікову структуру деревост нів. ротягом ост нніх років відбулися позитивні зміни у лісовому фонді.

о них н леж ть: збільшення його з г льної площі з вдяки прийняттю земель від колишніх колективних сільськогоспод рських підприємств, зрост ння лісистості, збільшення площі лісів першої групи н $12 \%$ з вдяки створенню з повідних об'єктів місцевого зн чення; зміни в породному скл ді, зокрем, збільшення н $1 \%$ площ хвойних деревост нів т дуб вн слідок з ліснення площ похідних деревост нів, підвищення продуктивності лісів, поліпшення с ніт рного ст ну деревост нів т їхніх рекре ційних пок зників.

\section{СПИСОК ВИКОРИСТАНОЇ ЛІТЕРАТУРИ}

1. нсірук . . іси кр їни / . . нсірук. - . : у ук. думк , 1992. - 408 с.

2. еогр фія олинської обл сті / [з ред. . . уцишин ]. - уцьк : , 1991. $163 \mathrm{c.}$

3. еренчук . . егіон льне природокористув ння : [н вч. посіб.] / . . еренчук. ьвів : [б. в.], 1992. - . 217-233.

4. косередовище і суч сність : у 2 т. .2. егіон льні процеси прогнозув ння й оптиміз ції екосередовищ / . . орогунцов, . . весик, . . орб ч, . . стушенко. - .: ондор, 2006. - 470 с.

5. $p$ вців . . кологічн політик у олинській обл сті: ст н, проблеми, перспективи : ( н літ. т прогр м. м тері ли) / . . р вців, . . ер симчук, . . іг с; [з ред. . . олішнього]. - уцьк : дстир'я, 2001. - 68 с.

6. іхович . . орм тиви оптим льної водоохоронної лісистості / . . іхович // одоохоронні лісон с дження. - . : рож й, 1986. - .22-38.

7. спорт річки ижівк / н-т “ олиньводпроект”. - уцьк : [б. в.], 1999. - 72 с.

8. ояснюв льн з писк до перспективного пл ну орг ніз ції і розвитку лісового господ рств . роект орг ніз ції і розвитку лісового господ рств / ерж. П-во 
“ т ровижівське лісове господ рство” олин. обл. упр. ліс. госп-в . . 1, кн. 1. рпінь : [б. в.], 2005. - 56 с.

9. озробк регіон льної прогр ми з хисту земель від водної т вітрової ерозії, інших видів дегр д ції земель олинської обл сті / кр. к д. гр рних н ук ; н-т землеустрою. олин. філія. - уцьк : [б. в.], 1995. - 53 с.

m ття: н дійшл до ред кцї̈ 10.07.2013

доопр иььов н 06.10 .2013

прийнят до друку 10.10.2013

\title{
FOREST FUND OF VYZHIVKA RIVER BASIN: CURRENT STATUS AND FEATURES OF USE
}

\author{
Nadia Chyr ${ }^{1}$, Mykhailo Melniychuk ${ }^{2}$, Roman Kacharovskyi ${ }^{2}$ \\ ${ }^{I}$ State institution of higher education "Uzhgorod National University", \\ Pidhirna Str., 46, UA - 88000, Uzhgorod, Ukraine \\ ${ }^{2}$ Lesya Ukrainka Eastern European National University, \\ Voli Ave, 13, UA - 43025, Lutsk, Ukraine
}

Current state of forest fund of Vyzhivka River basin was described and evaluated. Statistics and dynamics of forest reserves and composition of tree species and age structure of forests were analyzed. Groups of forests by economic importance and the main types of environmental management within forest fund of studied area were allocated. Both negative and positive sides of it were shown.

Key words: forest fund, forest species composition, age structure of forests, logging, reforestation.

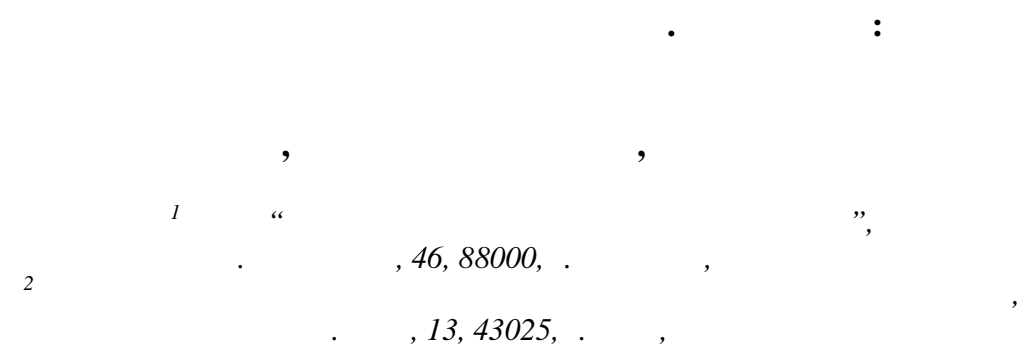

пис но и оценено современное состояние лесного фонд б ссейн р. ыжевк . ро н лизиров но ст тистические д нные и дин мику з п сов лесного фонд, его породного сост в и возр стной структуры лесон с ждений. ыделено группы лесов 3 хозяйственным зн чением и основные виды природопользов ния в предел х лесного фонд исследуемой территории. ок 3 но к к нег тивные, т к и позитивные его стороны.

лючевые слов : лесной фонд, породный сост в лесов, возр стн я структур лесон с ждений, з готовк древесины, лесовосст новление. 